\section{Geologist fails to overturn Creationist judgement}

[SYDNEY] Ian Plimer, the Australian professor of geology who has fought a five-year court battle against a Christian preacher's claims to have found 'scientific' evidence for Noah's Ark in Turkey, has lost his bid to overturn a judgement made against him last June.

Three Federal Court judges found unanimously last Friday (5 December) that the original judge, Ronald Sackville, was correct in dismissing Plimer's civil action against preacher Allen Roberts (see Nature 389,323 ; 1997). The presiding judge, John Davies, acknowledged that Roberts had made "misleading statements" in his lectures. But he concluded that such conduct was not an aspect of "trade or commerce", which was the basis claimed by Plimer for his charges against Roberts.

Outside the court, Roberts said Plimer had "sought to stifle our voice", and declared "a victory for freedom of belief and expression". Plimer admitted his "pockets now rattle after the appeal", and said he will file for bankruptcy.

Despite the setback, Plimer and his solicitor say they may appeal further to the High Court of Australia over the lack of protection for consumers - the basis of their challenge that creationism was being presented as science - implied by the Federal Court's judgement.

While the High Court may not give leave for an appeal, another court confrontation appears certain, as a suit for defamation brought by Roberts against Plimer was deferred until after the trade practices case. Plimer says he will immediately seek a trial date, believing he can plead evidence and issues of broader scope than were allowed under trade law.

Meanwhile, the Creation Science Foundation, a Brisbane-based evangelical group apparently unconnected with Roberts' group, has changed its name to 'Answers in Genesis'. The foundation, which teaches 'creation science' and campaigns for its inclusion in school curricula, claims scientific authority primarily through a staff member who holds a $\mathrm{PhD}$ in geology, and its director, who is a medical practitioner.

Barry Williams, executive officer of the Australian Skeptics, argues that the name change can be seen as a response to the threat of similar legal actions to Plimer's, and labels it as "a triumph for the side of reason and science". According to Williams, the foundation "has publicly confessed that what they do is not science, a very useful concession to our case".

Peter Pockley

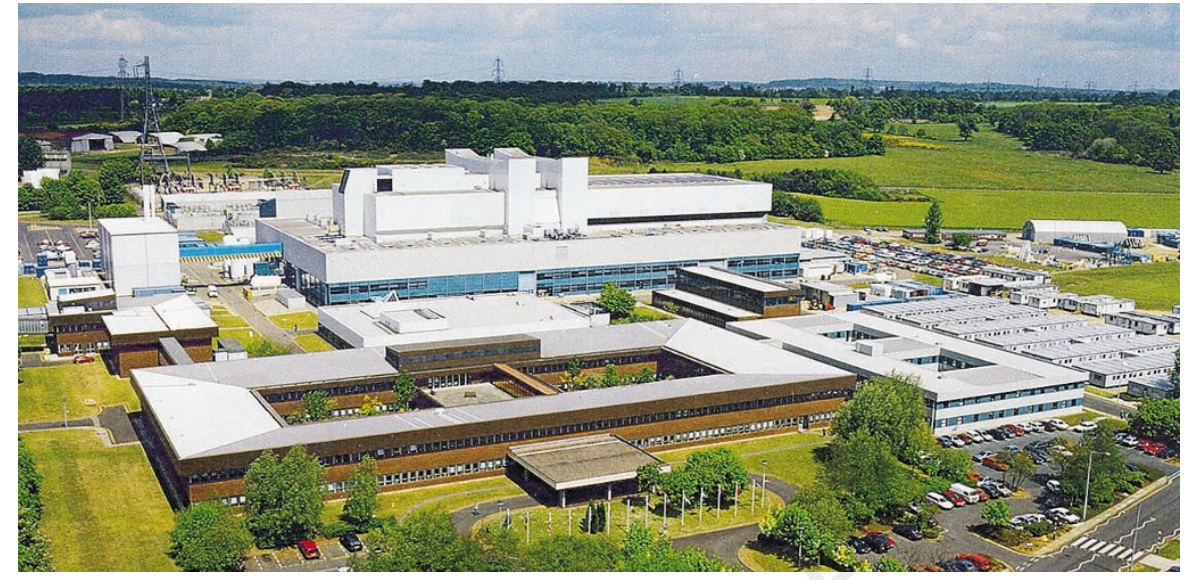

Rural calm? The JET fusion plant, source of a long-running employment disagreement.

\title{
Dispute blocks agreement on Europe's fusion funds
}

[MUNICH] British scientists working at the Joint European Torus (JET) fusion facility in Oxfordshire, England, have overwhelmingly rejected a settlement proposed by the European Parliament which could have resolved a fifteen-year labour dispute.

The dispute centres on the fact that the scientists are hired on contracts issued by the UK Atomic Energy Authority (UKAEA), whose terms are less advantageous than the European Atomic Energy Community (Euratom) contracts enjoyed by their nonBritish colleagues. Two-thirds of the JET scientists are hired by UKAEA.

The failure to reach a resolution has already led to the parliament blocking the 1998 budget for the entire European Union fusion programme in an attempt to force a negotiated settlement. The parliament's budget committee will decide next week how much of the fusion budget to release, and whether it wishes to continue trying to help resolve the dispute, which could affect any future extension of the JET programme beyond 1999.

The European Court of Justice ruled in 1987 that, although JET's dual employment system was discriminatory, the differences in contracts were justified as non-Britons had to live abroad and, at the time, lacked the prospect of a guaranteed job when the JET programme ends. After this ruling, the JET council gave the British scientists a one-off ex gratia payment of ECU2 million (US\$2.2 million) in compensation.

But in a second ruling last December, the court found that conditions had changed, as much of UKAEA had since been privatized, and the scaled-down organization was no longer capable of absorbing the British scientists when the JET joint undertaking comes to an end.

At the same time, the European Commission started actively seeking new positions for Euratom JET employees. This time the court ruled in favour of the UKAEA workers.

The commission, which funds 80 per cent of JET's costs, the JET council, the UKAEA and the British JET scientists entered negotiations on how the scientists should be compensated following the new ruling, but these broke down in early summer.

Employers were unable to meet the demands of the British scientists for either transfer to Euratom contracts, or full financial compensation, which would have totalled ECU21 million after tax, for the three-year JET programme. As the settlement would probably be subject to full taxation, this demand would actually have cost the programme around ECU45 million.

In an unusual move, the parliament decided to act as mediator in the negotiations. In its October plenary session, it blocked the 1998 fusion research budget in a bid to force the parties back to the negotiating table.

The settlement proposed by the parliament - but subsequently rejected by the British JET scientists — included transferring 25 Euratom JET positions to the general fusion programme, making them open to competition from British JET researchers, along with a total ex gratia payment of ECU9 million to the UKAEA staff in compensation.

Martin Keilhacker, director of the JET programme, says that the JET council, which met after last week's ballot, would have been prepared to accept the parliament's proposal as a final settlement of the dispute, "despite the burden this would have placed on JET's [very stretched] budget".

The parliament is expected to lift its block on the general fusion budget at its plenary session next week, while possibly holding back a reserve to cover future compensation payments. It is unlikely to continue to act as mediator in the dispute

Alison Abbott 